\title{
RESPONSE OF PEAR SEEDLINGS TO SOME NON-AND MAGNETIZED SALINE IRRIGATION WATER AND HUMIC ACID AND THEIR EFFECT ON GROWTH, LEAF PHYSIOLOGICAL PROPERTIES, LEAF PIGMENTS AND ELEMENTS CONTENTS
}

\author{
H. Kabeel(1), D. R. Darwesh(1)*, Y. I. El-Naggar (1) and A. M. A. Abd El-Hady(2) \\ (1) Horticulture Research Institute, Agriculture Research Center, Giza, Egypt \\ (1) Soil, Water and Environment Research Institute, Agriculture Research Center, Giza, \\ Egypt \\ * Corresponding author email: darwesh.abeed@gmail.com
}

Received: Aug. 26, 2020

Accepted: Sep. 22,2020

\begin{abstract}
This study was conducted during two successive seasons of 2018 and 2019 at El Kanater Horticultural Research Station, Qalyoubeia Government Egypt. The aim of this investigation was to study the effect of salinity levels of non-and magnetized irrigation water alone and in combination with humic acid on one-year-old pear seedlings (Pyrus communis) rootstock.
\end{abstract}

Obtained results revealed that, the two higher concentrations of saline water (1500 and $3000 \mathrm{mg} / \mathrm{l}$ ) resulted in a gradual significant decreased in all vegetative measurements, dry weights of pear seedling organs, both leaf succulence grade, water potential and leaf content of pigments as well as some leaf elements contents of $\mathrm{N}, \mathrm{P}, \mathrm{K}, \mathrm{Mg}, \mathrm{Fe}, \mathrm{Zn}$ and $\mathrm{Mn}$, Whereas an opposite trends were observed with leaf osmotic pressure, proline content and leaf content of $\mathrm{Ca}, \mathrm{Na}$ and $\mathrm{Cl}$ as compared to the control (270 $\mathrm{mg} / \mathrm{l}$-fresh water). On the other hand, seedlings treated with either humic acid or magnetized water were exited significantly an increasing values of vegetative parameters, dry weights of different plant organs, leaf pigments and some macro and micro-nutrients beside $\mathrm{Na}$ and $\mathrm{Cl}$ as well as both leaf succulence grade and water potential as compared to control (non-magnetized water or non-humic acid) in both seasons of study. The obtained data concluded that the use of magnetized water technique with humic acid applications would be efficiently and safe alternative tool to resolve the problem of irrigating with saline water and to enhance pear rootstock seedlings growth grown under similar conditions of this study.

Key words: Pear seedlings, Magnetized water, Saline water, Humic acid, Growth parameters.

\section{INTRODUCTION}

Pear can be considered as one of the major and most important deciduous fruits in Egypt. For that, in the few last decades the areas cultivated with pear was enormously increased to meet the continuous rise in demand for pear fruits for local consumption in Egyptian markets. Serious water shortage becomes the most important problem in Egypt. There is an urgent need to use alternative water sources for irrigation in order to conserve fresh water. Moreover, the expansion of agricultural land need amounts of suitable irrigation water which already is not sufficient to meet all the expected demands in this respect. On the other hand, in Egypt, the supply of water for use in agriculture is becoming increasingly limited while agriculture the main consumed about $80 \%$ of the available water where crop production is based mainly on irrigation.

Under the population pressure in Egypt, the need to provide an additional land in future than the present which may 
required additional water to face high demands from the ever-increasing population and the expansion of irrigated area for farming to increases food production (Mohamed,2013). Thus, there is a pressing need for system (technology role e.g. magnetic water) saline water treated by passing through a magnetic device called magnetized water, for that, saline water may represent a possible water supply for agriculture production, but it requires innovative and sustainable research and an appropriate transfer of technology.

The successful use of magnets in treating water for irrigation, industry and home use was used in many countries of the world (China, Japan, Australia, Russia, United States and many European countries)(Qudos and Hozayn,2010).

Magnetic water may improved the plant growth characteristics and nutrients uptake (Radhakrishnan and Kumari, 2012), root function (Aladjadjiyan, 2010), as well as chemical composition of plants and plant enzymes (Alikamanoglu and Sen, 2011), Moreover, using magnetic irrigation water was superiority than nonmagnetic irrigation water whish gave the best results on vegetative growth, fruiting and yield and increased leaf mineral composition of $\mathrm{N}, \mathrm{P}$ and $\mathrm{k}$ and improved fruit quality (Aly et al., 2015) on Valencia orange trees. On the other hand, the same trend was observed with seedlings of Date palm (Dhawi and Al-Khayri, 2009), Pear betulaefolia rootstock (Osman et al., 2014)) and Soliman et al. (2017) who found that irrigation with magnetized water led to a decrease in $\mathrm{pH}$ values in soil samples at different depths comparing to soils irrigated with non-magnetized water. Also data show irrigation with magnetized water led to a decrease in EC and soluble ions contents in soil samples at different depths comparing to soils irrigated with non-magnetized water.
The use of magnetized water for irrigation have the positive effect to save irrigation water and the less harmful influence on the environment (Mostafazadeh et al., 2011) Irrigation with magnetized water increased significantly the growth characteristics, kinetin, GA3, nucleic acids (RNA and DNA), potassium, photosynthetic pigments (chlorophyll a and $b$ and carotenoids), photosynthetic activity and translocation efficiency of photo-assimilates as compared with control plants as reported by Moussa, (2011) and Soliman et al. (2017).

Humic acids (HA) are the most active components of soil and compost organic matter, stimulate plant growth and consequently yield by acting on mechanisms involved in cell respiration, photosynthesis, protein synthesis, water and nutrient uptake, enzyme activities (Chen et al., 2004), In particular, optimal concentrations able to affect and stimulate plant growth have been generally found in the range of $50-300 \mathrm{mg} /$ $L$, but positive effects have been also exerted by lower concentrations (Chen et al., 2004). A distinction on the effects of humic acids should be made between indirect and direct effects on plants growth. Indirect effects are mainly exerted through properties such as enrichment in soil nutrients, increase of microbial population, higher cation exchange capacity, improvement of soil structure; whereas direct effects are various biochemical actions exerted at the cell wall, membrane or cytoplasm and mainly of hormonal nature (Varanini and Penton, 2001; Chen et al., 2004).

Therefore, the objective of the current investigation is to evaluate the most effective treatments with salinized water at different concentrations $(270,1500$ and $3000 \mathrm{mg} / \mathrm{l}$ ) either alone or combined with magnetized or non-magnetized water and two treatments of both humic acid (0.0 and $30 \mathrm{~cm}$.) on some vegetative growth 
parameters, leaf physiological properties and leaf chemical analysis of pear communis rootstock seedlings.

\section{MATERIAL AND METHODS}

The present investigation has been carried out throughout the two consecutive seasons of 2018 and 2019 in the Experimental Farm at El Kanater Horticultural Research Station, Qalyoubeia Government, Egypt. One hundred and eight uniforms in vigor and healthy one-year-old seedlings of pear rootstock (Pyrus communis) were the plant used in this study and transplanted individually in plastic bag of $30 \mathrm{~cm}$ in diameter during the first week of February and filled with media consisting of clay and sandy at equal proportion by volume.

Some physical and chemical properties of the soil at the used media which were determined before transplanting are presented in Tables (1).

Pear seedlings were representative of the different twelve combination treatments between three factors i.e. (a) three levels of saline water concentrations (270, 1500 and $3000 \mathrm{mg} / \mathrm{l}$.), (b) two types of irrigation water treatments (nonmagnetized water and magnetized water) and (c) two rates of humic acid solution (HA) at $(0.0$ and $30 \mathrm{~cm} . /$ seedling/year) where the major constituent of humic acid is potassium humate " $85 \%$ " and folvic acid "3\%".

The different studied treatments applied were as follows:

1. Fresh and non-magnetized Nile water at $270 \mathrm{mg} / \mathrm{l}+0.0 \mathrm{~cm}$ HA (control)

2. Fresh and magnetized Nile water at $270 \mathrm{mg} / \mathrm{l}+0.0 \mathrm{~cm} \mathrm{HA}$

3. Fresh and non-magnetized Nile water at $270 \mathrm{mg} / \mathrm{l}+30 \mathrm{~cm} \mathrm{HA}$

4. Fresh and magnetized Nile water at $270 \mathrm{mg} / \mathrm{l}+30 \mathrm{~cm}$ HA

5. Non-magnetized saline water at $\mathbf{1 5 0 0}$ $\mathrm{mg} / \mathrm{l}+0.0 \mathrm{~cm}$ HA

6. Magnetized saline water at $\mathbf{1 5 0 0} \mathrm{mg} / \mathrm{l}+$ $0.0 \mathrm{~cm} \mathrm{HA}$

7. Non-magnetized saline water at $\mathbf{1 5 0 0}$ $\mathrm{mg} / \mathrm{l}+30 \mathrm{~cm}$ HA

8. Magnetized saline water at $1500 \mathrm{mg} / \mathrm{l}+$ $30 \mathrm{~cm} \mathrm{HA}$

9. Non-magnetized saline water at $\mathbf{3 0 0 0}$ $\mathrm{mg} / \mathrm{l}+0.0 \mathrm{~cm} \mathrm{HA}$

10. Magnetized saline water at $3000 \mathrm{mg} / \mathrm{l}+$ $0.0 \mathrm{~cm} \mathrm{HA}$

11. Non-magnetized saline water at $\mathbf{3 0 0 0}$ $\mathrm{mg} / \mathrm{l}+0.30 \mathrm{~cm}$ HA

12. Magnetized saline water at $3000 \mathrm{mg} / \mathrm{l}$

$+0.30 \mathrm{~cm} \mathrm{HA}$

Table (1): Physical and chemical properties of the used media.

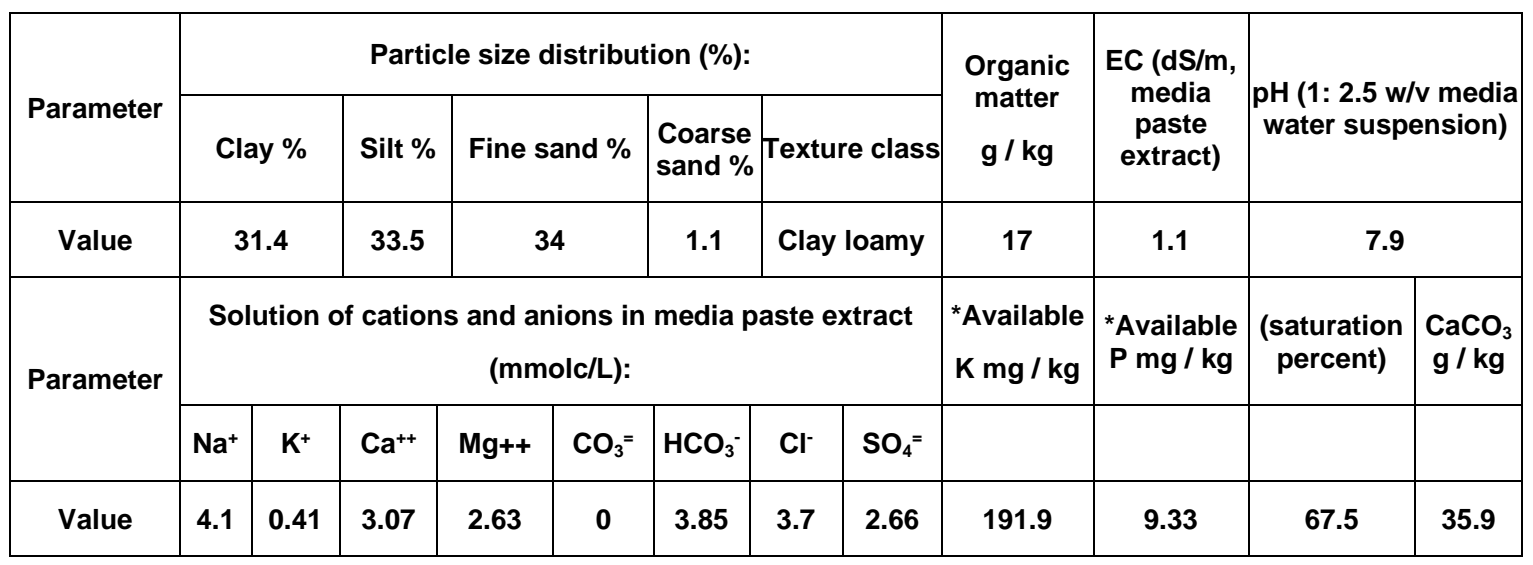

* Extracts of $\mathrm{NH}_{4}$ - acetate (for $\mathrm{K}$ ), and sodium bicarbonate (for $\mathrm{P}$ ). 
The plants were irrigated with fresh water till the 30th of April, until the beginning of the experimental treatments. Prior to irrigation, seawater was diluted with fresh water to the required concentrations (1500 and $3000 \mathrm{mg} / \mathrm{l})$ in plastic tank. The diluted seawater was used for irrigation throughout the course of the study that extended to seven months.

Irrigation water passed through a magnetic device ( 2 inch, output $18 \mathrm{~m}^{3}$ per hour, 4500 gauss, Made in Germany). The device comprised of two magnets, arranged to the north and south poles. The directions of magnetic field generated at the flow rate as shown in (Fig. 1).

The used three saline irrigation water were both non- and magnetized saline water analyzed for their PH and EC and the obtained data are recorded in Table (2).

The studied treatments were arranged in a factorial experiment as conducted using a complete randomized block design where each treatment was replicated three times and each replicate was represented by three seedlings.
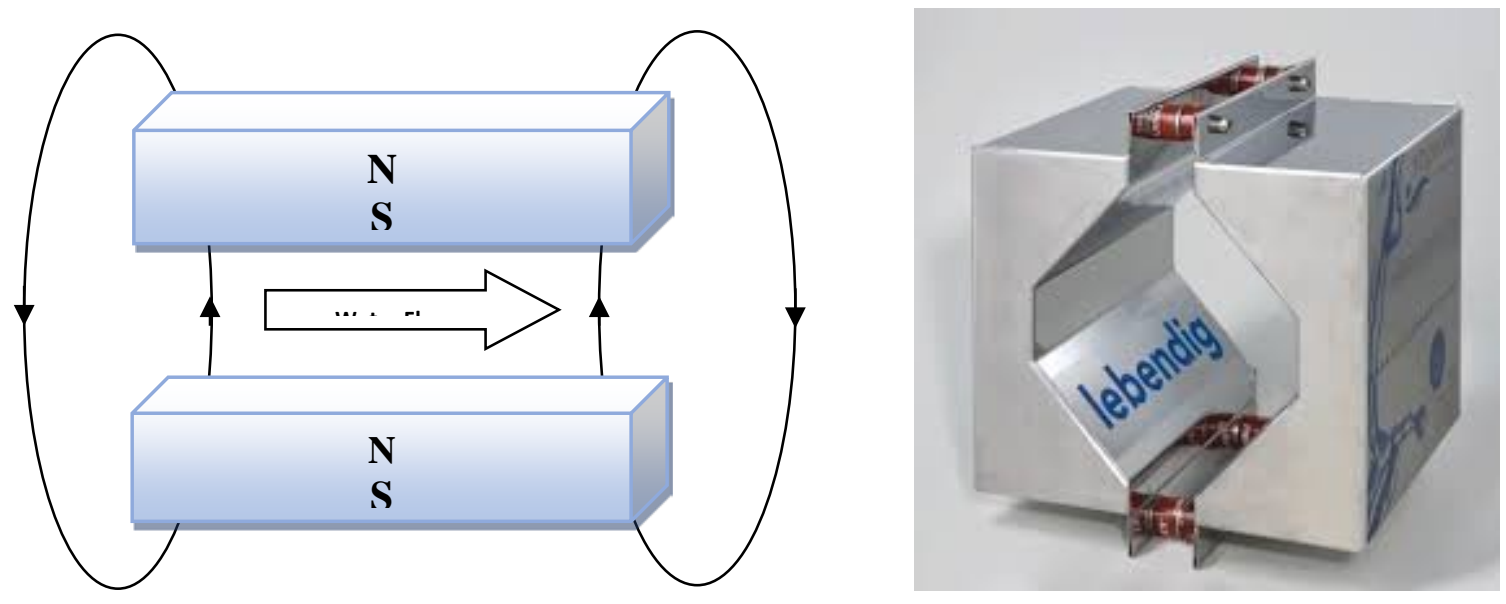

Fig. 1: Schematic of magnetic fields and direction of water flow during the magnetic treatment.

Table (2): Effects of magnetic treatment on mean values of $\mathrm{pH}$ and EC in different types of irrigation waters.

\begin{tabular}{|c|c|c|c|c|}
\hline \multirow{2}{*}{ Irrigation water type } & \multicolumn{2}{|c|}{$\mathrm{pH}$} & \multicolumn{2}{c|}{ EC (dS/m at 25 $\mathrm{C}$ ) } \\
\cline { 2 - 5 } & $\begin{array}{c}\text { Non- } \\
\text { Magnetized } \\
\text { water }\end{array}$ & $\begin{array}{c}\text { Magnetized } \\
\text { water }\end{array}$ & $\begin{array}{c}\text { Non } \\
\text { Magnetized } \\
\text { water }\end{array}$ & $\begin{array}{c}\text { Magnetized } \\
\text { water }\end{array}$ \\
\hline Fresh water $270 \mathrm{mg} / \mathrm{l}$ & 8.15 & 8.13 & 0.422 & 0.417 \\
\hline Saline water $1500 \mathrm{mg} / \mathrm{l}$ & 8.40 & 8.36 & 2.37 & 2.35 \\
\hline Saline water $3000 \mathrm{mg} / \mathrm{l}$ & 8.41 & 8.36 & 4.74 & 4.70 \\
\hline
\end{tabular}


Methodology as has been followed in this investigation is being determined as follows:

\section{Morphological characteristics (some vegetative growth) parameters:}

In both seasons, the effect of the different studied treatments on some vegetative growth measurements were recorded, the measured growth parameters were: plant height $(\mathrm{cm})$, number of leaves /plant, leaf area $\left(\mathrm{cm}^{2}\right)$ and dry weights $(\mathrm{g})$ of three plant organs leaves, stem and roots.

\section{Physiological properties of leaf:}

The following three physiological characters of pear leaves were investigated as follows:

a) Leaf succulence grade (L.S.G.): Was calculated as gram $\mathrm{H}_{2} \mathrm{O} / \mathrm{cm}^{2}$ of leaf area according to Nomir, (1994) as following equation:

L. S. G. =

$$
\frac{\text { Leaf water content }(\mathrm{gm})}{\text { Leaf area }(\mathrm{cm})^{2}} \mathrm{gm} \mathrm{H}_{2} \mathrm{O} / \mathrm{cm}^{2} \text { of leaf }
$$

Whereas,

\section{Leaf water content $(\mathrm{gm})=$}

leaves fresh weight - leaves dry weight at end of experiment $\times 100$ Number of leaves at the end of experiment

b) Leaf water potential (L.W.P.): Was estimated as following equation as suggested by Halma, (1934) and confirmed by Peynado and Young, (1968).

Leaf water potential $=\frac{\text { Fresh weight }- \text { dry weight }}{\text { Fresh } \text { weight }} \times 100$

c) Leaf osmotic pressure in bar (L.O.P.): Was estimated according to the method described by (Gusov, 1960).

3. Chemical analysis:

a) Leaf chlorophyll contents ( $a, b$ and carotenoids): Which were expressed as $\mathrm{mg} / \mathrm{g}$ fresh weight and calculated according to the method described by (Saric et al., 1967) using the following equations:

Chlorophyll A $=(9.784 \times$ E 662) $)-(0.99 \times E$ 644) $=\mathrm{mg} / \mathrm{g}$ fresh weight

Chlorophyll B $=(21.426 \times$ E 644) $)-(4.650 x$ $E$ 662) $=\mathrm{mg} / \mathrm{g}$ fresh weight

Carotenoids $=(4.685 \times$ E 440 $)-(0.268 \times$ chl. $a+$ chl. $b)=\mathrm{mg} / \mathrm{g}$ fresh weight

b) leaf proline content: Was estimated in fresh leaves according to the method described by Batels et al., (1973) and confirmed by Draz, (1986).

c) Leaf nutritional status: Leaf contents of some macro-elements $\mathbf{N}$, $\mathrm{P}, \mathrm{K}, \mathrm{Ca}, \mathrm{Mg}, \mathrm{Na}$ and $\mathrm{Cl}$ as well as the content of micro-nutrients $\mathrm{Fe}, \mathrm{Zn}$ and Mn were determined. A $0.5 \mathrm{~g}$ of leaves dry materials was digested in $10 \mathrm{ml}$ of concentrated $\mathrm{H}_{2} \mathrm{SO}_{4}$ and $\mathrm{HClo}_{4}$ mixture at mixed ratio of 3:1 as described by Chapman and Pratt (1961). The following procedures were used: Total nitrogen was determined by microKjeldahl method described by Cottenie et al., (1982). Whereas, P was determined colorimetrically according to Murphy and Riely (1962). However, other elements $(\mathrm{K}, \mathrm{Ca}, \mathrm{Mg}, \mathrm{Na}, \mathrm{Cl}, \mathrm{Fe}$, $\mathrm{Zn}$ and $\mathrm{Mn}$ ) were determined by using the Atomic Absorption Spectrophotometer (3300) according to Chapman and Pratt (1961).

Soil analysis:

Particle size distribution was conducted using the pipette method according to Klute (1986). Media pH, electric conductivity (EC) and content of soluble cationic and anionic compositions of the saturation extract of the soil were determined according to the standard methods described by Page et al., (1982). 


\section{Statistical analysis:}

All obtained results during two seasons were statistically analyzed using analysis of variance method according to Snedecor and Cochran, (1990). However, significant differences among means distinguished according to the Duncan's multiple test range (Duncan, 1955).

\section{RESULTS AND DISCUSSIONS}

1. Effect of the studied treatments on morphological characteristics:

a. Vegetative growth measurements:

Referring the effect of salinity levels on some vegetative growth measurements i.e. plant height $(\mathrm{cm}$.), root length $(\mathrm{mm})$ and both number of leaves Iplant and leaf area $\left(\mathrm{cm}^{2}\right)$ of communis pear rootstock seedlings, data presented in Table (3) revealed that, both two saline water concentrations of (1500 and 3000 $\mathrm{mg} / \mathrm{l}$ ) exhibited an obvious decrease in four vegetative measurements abovementioned during the two seasons of study. Such decrease was significant as compared to the control (seedlings irrigated with fresh and non magnetized Nile water, $270 \mathrm{mg} / \mathrm{l}$ ) which resulted significantly in the highest plant height, the longest root, the higher number of leaves/plant and the largest leaf area. Meanwhile the saline treatment of water at rate of $3000 \mathrm{mg} / \mathrm{l}$ gave statistically the lowest plant height, the shortest root and the least number of leaves/plant more than those found with the treatment of $1500 \mathrm{mg} / \mathrm{l}$. Furthermore, the differences between the three salinity concentrations were significant. Such trends were true during both 2018 and 2019 seasons of study. With respect to the effect of humic acid treatment, data displayed clearly that, pear seedlings treated with humic acid resulted in significantly increase for all vegetative growth parameters abovementioned in this study as compared to the other treatment in the two growing seasons.

Concerning the effect of magnetized water used for irrigation on four vegetative charactars under study, data Table (3) indicated that, the magnetized water for irrigation exhibited a significant increase in plant height, root length, number of leaves /plant and leaf area $\left(\mathrm{cm}^{2}\right)$ as compared to the other treatment of communis pear seedlings rootstock.

Regarding the interaction effect of three investigated factors (salinity, and magnetized water humic acid) used on four vegetative growth parameters abovementioned, obtained data in Table (3) showed obviously that, a significant effect on four studied vegetative growth parameters of communis pear rootstock seedlings during the two seasons of study was observed. However, the highest decrease in plant height (cm.), root length $(\mathrm{mm})$, number of leaves/plant and leaf area $\left(\mathrm{cm}^{2}\right)$ were resulted by those pear seedlings treated with the highest salinity concentration (3000 mg/l), combined with both non magnetize water and non humic acid added i.e.(3000 mg/l, non magnetized water and non humic acid) treatment as compared to the other investigated combination treatments. Meanwhile, the lowest decrease in vegetative parameters abovementioned was associated with those seedlings with that combination between the lowest salt concentration(270 $\mathrm{mg} / \mathrm{l})$ with magnetized water and higher rate of humic acid (30 cm humic acid) i.e. $(270 \mathrm{mg} / \mathrm{l}$, magnetized water and $30 \mathrm{~cm}$ humic acid) treatment. In addation to that, the other remain combination treatments came intermediate between the aforsaid two extremes. Such trends were detected during both 2018 and 2019 seasons of study. 


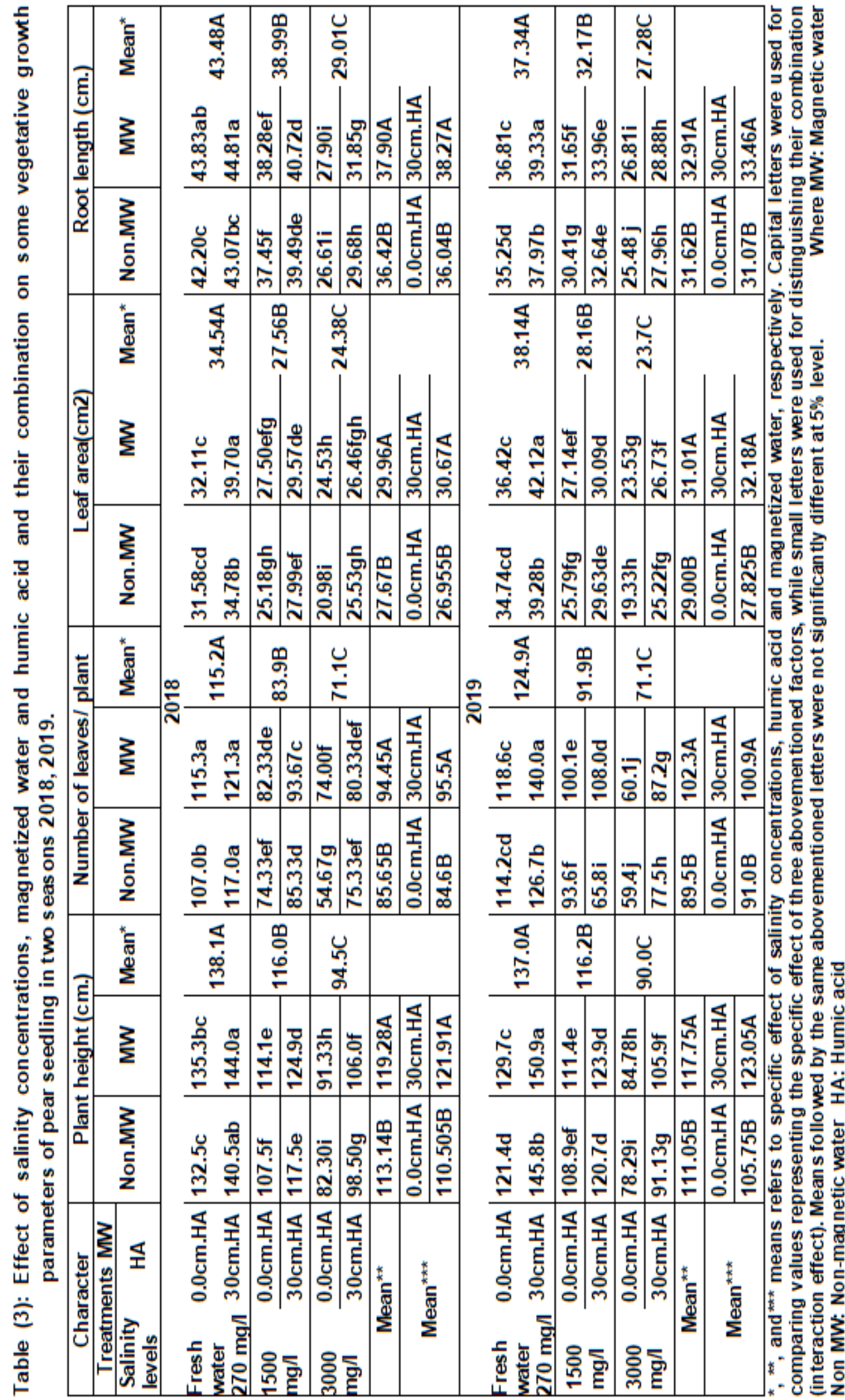


b. Dry weight of seedling organs (leaves,stem and root) of communis pear.

Concerning the effect of salt concentrations, data obtained in Table (4) revealed obviusly that, both two higher investigated concentrations of saline water (1500 and $3000 \mathrm{mg} / \mathrm{l})$ resulted in a gradual decrease in dry weights of all seedling pear organs (leaves,stem and roots) during the two expermental seasons of study. Such decrease was significant as compared to those pear seedlinged treated with the lower saline water concentration $(270 \mathrm{mg} / \mathrm{l})$ i.e. Nile water (control) which resulted in the greatest values of dry weights of plant organs. On the other hand, the most depressive effect and greatest loss in dry weights of all seedling organs (leaves,stems and roots) were always in concomitant to the highest salt concentration (3000 mg/l), meanwhile, salt concentration of $(1500 \mathrm{mg} / \mathrm{l})$ was intermediate in this respicet. Moreover, the differences between the three treatments $(270,1500$ and $3000 \mathrm{mg} / \mathrm{l})$ were significant as each was compared to the two other ones for the studied abovementioned measurements of communis pear seedlings during both 2018 and 2019 seasons of study.

Regarding the effect of magnetized water on dry weights of seedling organs (leaves,stems and roots) of communis pear rootstock, it is quite evident from resualts tabulated in Table (4) that using of magnetized water for irrigation exhibited an increasing in dry weights and resulted in the greatest value of different seedling organs as compared to the seedlings were irrigated with non magnetized water which showed the least values in dry weights of plant organs of communis pear seedlings rootstock. Such trend was true during the first and the second seasons of study.
Considering the effect of humic acid treatments on dry weights of plant organs under study, it is quite clear from presnt data in Table (4) that, the higher rate of humic acid $(30 \mathrm{~cm} H A)$ resulted in a significantly increase in all abovementioned studied measuerments than the lower one $(0.0 \mathrm{~cm} \mathrm{HA})$. Such trend was detected during both seasons of study.

Obtained results concerning the abovementioned growth measuerments were in harmony with the conclusion reported by Al- yassin (2005) and Brito et al., (2014) on citrus trees and Paranava et al. (2014) on mango seedlings where thay all revealed that, all groth prameters investigated were decreased by increased the concentration of salt in irrigation water. On the other hand, Osman et al. (2014) on pear seedling and Aly et al., (2015) on valancia trees and Soliman et al. (2017) on grape they reported that, application of magnetized water improved aforesid growth measuerments investigated under study as compared to non-magnetized water treatments.

In general, it could be concluded that, the greater growth under magnetized water and humic acid could be explained that,water stress decreased cytokine transport from root shoots and increased in amounet of leaf abscisc acid. These changes in hormone balance cause reduction in shoot growth and enlargment as well as leaf expansion Atkinson et al. (2000) also, reduction in growth under water stress conditions could be attributed to lower photosynthetic rate and stomatel conductence (Mpelasoka et al., 2001) Moreover, magnetic water wereased the growth by decreasing the hydratis of salt ions and colloids, having apositive effect on salt solubilty leading to leaching of soil salts. 


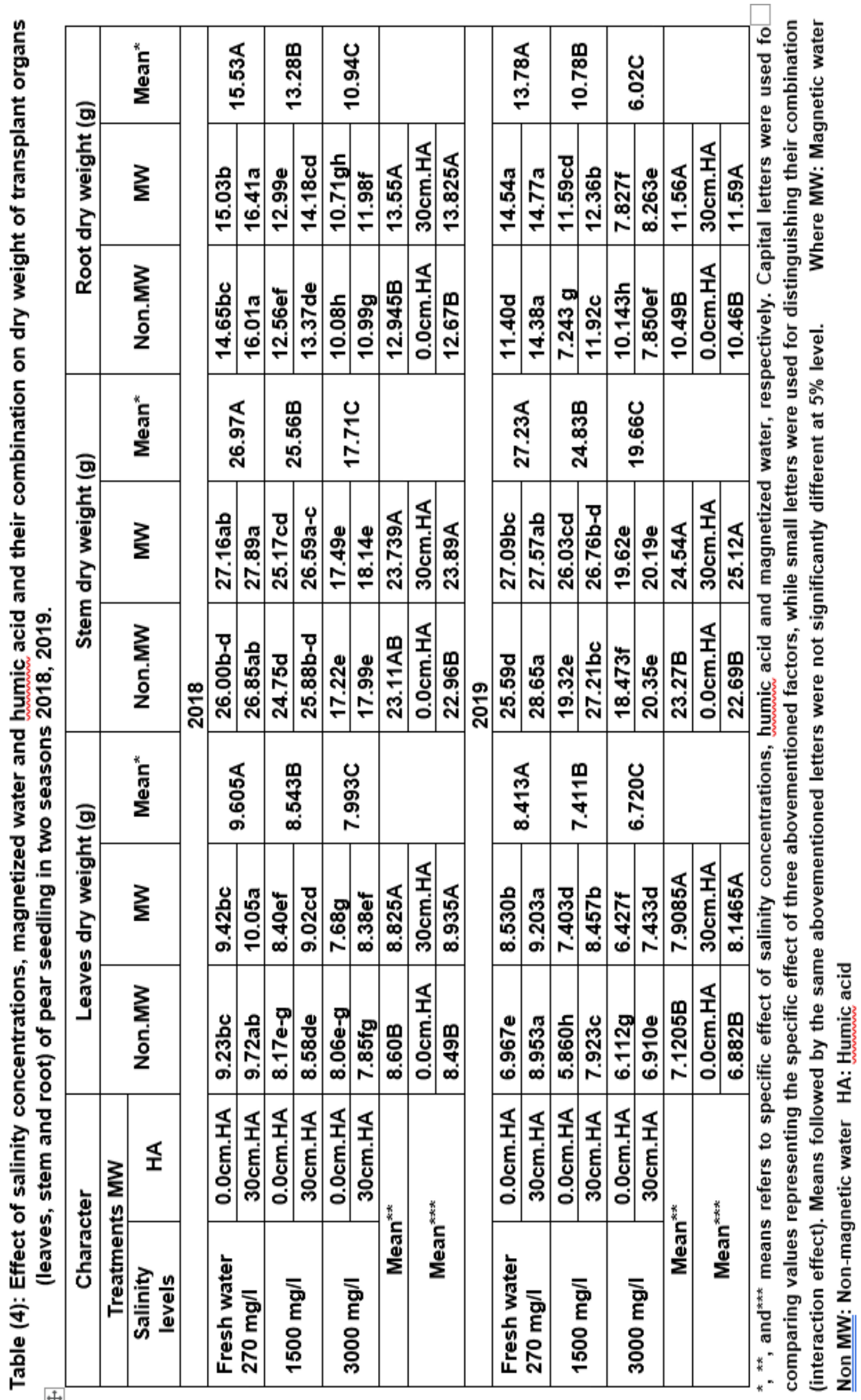


Furthermore, The beneficial effect of humic acid on growth of plant could be related to the improvement the physical condition of the soil, and increasing nutrients supply as well as improving the efficiency of macro-nutrients and its ability to meet some micro-nutrients rements (El-Nagar, (1996).

\section{Effect of the studied treatments on} leaf succulence grade and leaf water potential as well as leaf osmotic pressure:

With respect to the effect salt concentrations on leaf succulence grade, leaf water potential and leaf osmotic pressure, it is clear from data tabulated in Table (5) that, a significant relationship was detected between such characters and salt concentration in irrigation water. However, value of leaf osmotic pressure increased significantly with increasing salt concentration in irrigation water from $270 \mathrm{mg} / \mathrm{l}$ (control) up to $3000 \mathrm{mg} / \mathrm{l}$ in communis pear seedlings rootstock during both 2018 and 2019 seasons of study.

On the other hand, it was noticed from obtained results as shown in Table (5) that, an obvious gradually decreased in the percentage of both leaf succulence grade and leaf water potential with increasing salt concentration in irrigation water. Such decrease in leaf succulence grade and leaf water potential was significant as each concentration was compared to the other one or to those of the control treatment $(270 \mathrm{mg} / \mathrm{l})$. Moreover, the most depressing effect was closely related to the highest salinity concentration (3000 $\mathrm{mg} / \mathrm{l})$ which exhibited the least values of both leaf succulence grade and leaf water potential throughout the two seasons of study. On the contrary, the least decrease of leaf water potential $\%$ was in closed relationship with the lowest salt concentration in irrigation water (270 $\mathrm{mg} / \mathrm{l}$, control), meanwhile the saline solution of $1500 \mathrm{mg} / \mathrm{l}$ concentration was intermediate in this respect. Such trends were true during both 2018 and 2019 experimental seasons.

Referring the effect of humic acid levels on abovementioned characters of leaf succulence grade and leaf osmotic pressure, obtained results in Table (5) pointed out that, the leaf osmotic pressure was statistically decreased with the higher humic acid levels $(30 \mathrm{~cm})$ as compared to the lower humic acid rate $\mathbf{0 . 0}$ $\mathrm{cm})$. This trend was detected with communis pear seedling during the two experimental seasons of study. Furthermore, considering the effect of humic acid levels on leaf succulence grade and leaf water potential, it could be observed from data represented in Table (5) that, both leaf succulence grade and leaf water potential were increased significantly by increasing humic acid levels from 0.0 to $30 \mathrm{~cm}$. Similar trend was true with communis pear seedlings rootstock in the two seasons of study.

With regard to the effect of magnetized water used in irrigation of communis pear seedlings on leaf osmotic pressure from one hand and both leaf succulence grade and Leaf water potential characters from the second one, data obtained in Table (5) revealed that, two conflicted trends were detected. However, both leaf succulence grade and leaf water potential \% were significantly increased by irrigated with magnetized water which showed the greatest value as compared to the other treatment (seedlings irrigated with non magnetized water) which exhibited statistically the lowest value in this concern. On the contrary, the trend of response for leaf osmotic pressure as influenced by magnetized water and non magnetized water took the other way around, where characteristic was significantly decreased by irrigated communis pear seedlings rootstock with magnetized water. 


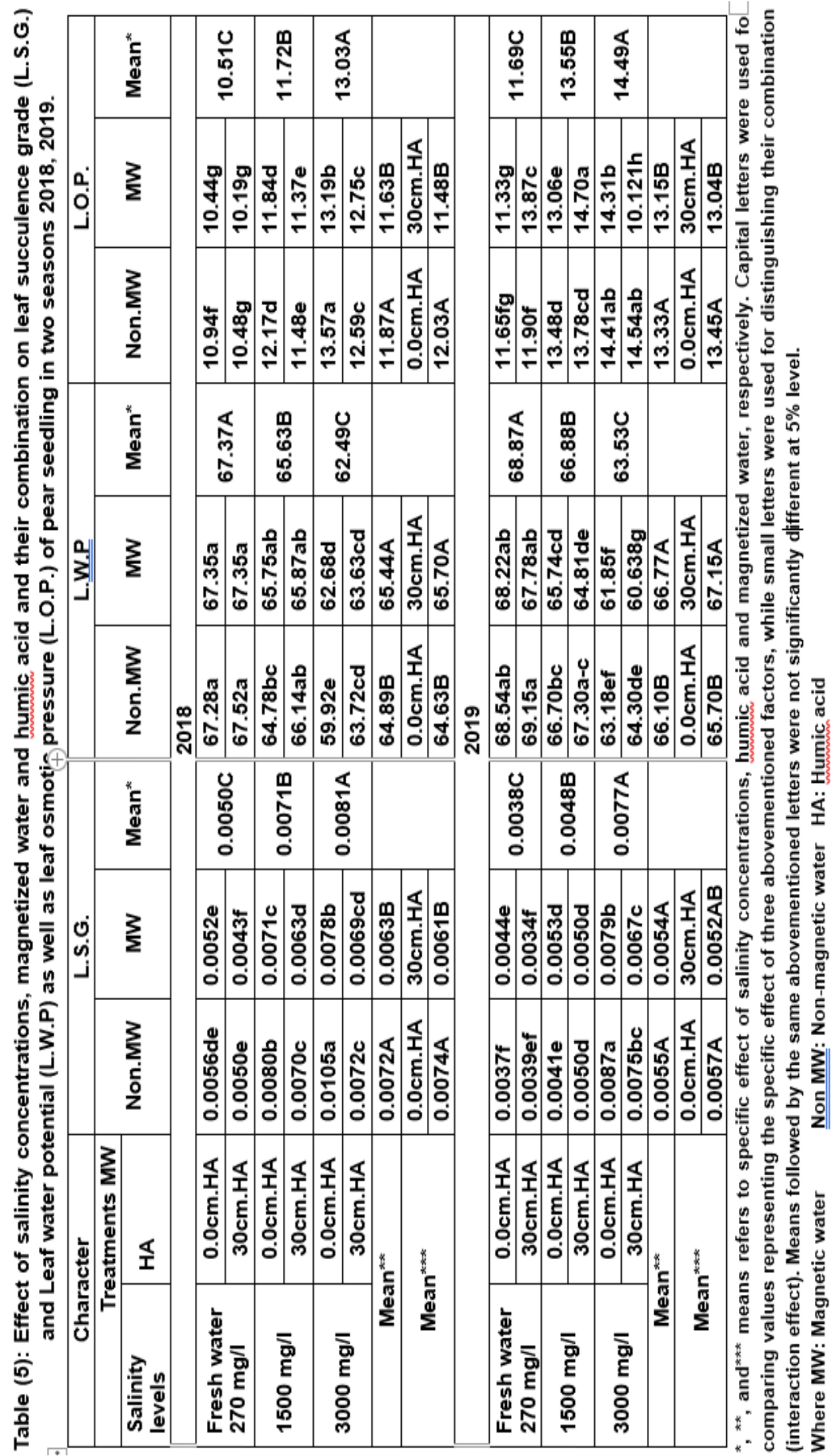


Data in Table (5) indicated that, specific effect of each investigation factor was reflected directly on the interaction effect of its combination. In the other words, pear seedlings irrigated with the highest salt concentration combined with the lower level of humic acid and irrigated with non-magnetized water i.e. $(3000 \mathrm{mg} / \mathrm{l}$, $0.0 \mathrm{~cm} \mathrm{HA}$ and non-magnetized water) treatment statistically exhibited generally the lowest value of both leaf succulence grade and leaf water potential as compared to either other combination treatments or control. Meanwhile, the least effective irrigation saline solution on increasing the leaf succulence grade and leaf water potential were that combination between the least salt concentration, the higher level of humic acid and irrigated with magnetized water i.e. $(270 \mathrm{mg} / \mathrm{l}, 30$ cm HA and magnetized water) treatment.

\section{Effect of the studied treatments on some chemical constituents:}

a. Leaf content of chlorophyll A, B and carotenoids:

Data obtained in Table (6) displayed obviously that a negative relationship was noticed between all investigated saline solution treatments $(270,1500$ and 3000 $\mathrm{mg} / \mathrm{l})$ and leaf content of pigments ((chlorophyll A,B and carotenoids). However, it could be observed that agradual decrease in level pigments content such was shown as salinity in irrigation water was increased during both seasons of study.

Wheras, the most depression effect was always related with the hight salt concentration $(3000 \mathrm{mg} / \mathrm{l})$ while the lowest decrease and the highest of level pigments content was resulted by the control treatment $(270 \mathrm{mg} / \mathrm{l})$.

Since, the treatment of $(1500 \mathrm{mg} / \mathrm{l})$ was inermediate in this cocern. Moreover, it could be mentioned that, the differences between three salinity treatments on the level pigments content (chlorophyll A,B and carotenoids) of communis pear rootstock seedlings in both 2018 and 2019 seasons of study were significant.

As for the obtained results regarding the effect of both HA and magnetized water treatments on the leaves contents of chlor.A,B and carot. Also data in Table (6) that, increasing both HA from 0.0 to 30 $\mathrm{cm}$ in irrigation water from one hand and using the magnetized water in irrigation from the other were exhibited significantly an increasing in photosynthetic pigments of leaves chlor.A,B and carot. contents. Moreover, such increase were significant as compared to pear seedlings irrigated with either non- magnetized water or non $\mathrm{HA}$ added $(0.0 \mathrm{~cm} \mathrm{HA})$ during the first and the scond seasons of study.

Data obtained concerning the interaction effect of different combination between three investigated factors (salinity concentration, magnetized water and humic acid) on leaves chlorophyll content during both seasons of study and represented in Table (6) displayed obviously that, pear seedlings irrigated with the highest concentrated saline water (3000 mg/l) combined with both lower level of HA $(0.0 \mathrm{~cm})$ and non-magnetized water had statistically the poorest leaves in their chlorophyll $A, B$ and carotenoids contents. On the contary, the oppesite trend was detected with pear seedlings supplied continuously with saline solution of $270 \mathrm{mg} / \mathrm{l}$ (control) combined with the higher level of HA $(30 \mathrm{~cm})$ and magnetized water treatment which had significantly the richest leaves in their chlorophyll A, B and carotenoids contents. In addition to that other combinaion treatments were in between the abovementioned two extremes with relatively variable tendency in their effectiveness. Such trends were detected during both the first and the scond seasons of study. 


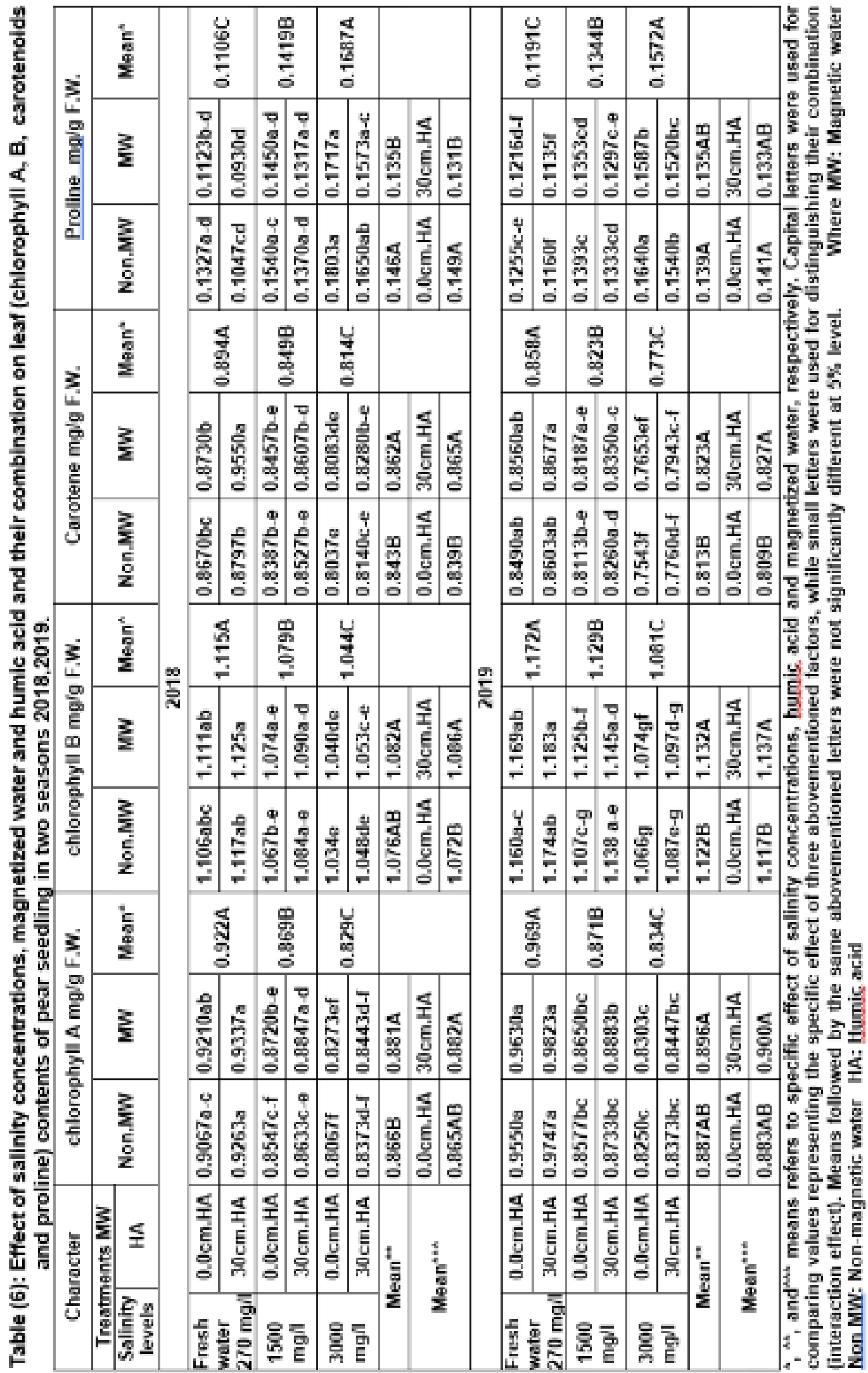


Obtained results are in harmony with those results reported by Moussa (2011) and Soliman et al. (2017), they found that irrigation magnetized water increased significantly the growth characteristics, photosynthetic activity and translocation efficiency of photo-assimilates and photosynthetic pigments (chlorophyll a, b and carotenoids), as compared with control plants.

\section{b. Effect of Leaf proline content:}

Considering the effect of saline water used on leaf porline content, it was noticed from obtained resultes in Table (6) That, porline content in the leaves of communis pear seedlings rootstock increased significantly and gradually with increasing the salt concentrations of the irrigation water from 270 to $3000 \mathrm{mg} / \mathrm{l}$. However, pear seedlings rootstock irrigated with the saline water of $3000 \mathrm{mg} / \mathrm{l}$ had statistically the richest leaves of porline content, followed by descending order by those irrigated with $1500 \mathrm{mg} / \mathrm{l}$ saline solution. Wheras, seedlings irrigated with the lowest salt concentration (270 $\mathrm{mg} / \mathrm{l}$,control) treatment. Obtained results are in harmony with those results reported by Soliman et al. (2017), Proline content increased significantly in leaves of grape after magnetic treatment.

\section{c. Leaf mineral contents:}

It could be noticed from data presented in Table (7, 8 and 9) that, $\mathrm{N}, \mathrm{P}, \mathrm{K}, \mathrm{Mg}, \mathrm{Fe}$, $\mathrm{Zn}$ and $\mathrm{Mn}$ content in leaves decreased significantly with increasing salinity concentration in irrigation water (1500 and $3000 \mathrm{mg} / \mathrm{l})$ compering of those the control (fresh Nile water, $270 \mathrm{mg} / \mathrm{l}$ ) which appeared contain usually the higher levels of abovementioned nutrients than those in salinized ones during both seasons of study. However, the opposite trend was remarkable for seedlings irrigated with saline water at the higher salt concentrations (3000 and1500 mg/l) which was significantly increased and gave richest leaves content in $(\mathrm{Ca}, \mathrm{Na}$ and $\mathrm{Cl})$ with increaseing saline water concentrations (3000 and1500 mg/l) as compered to those of control treatment which induced the last values of $(\mathrm{Ca}, \mathrm{Na}$ and $\mathrm{Cl}$ ) these results are similar to that reported by Mesut et al. (2010), who suggested that the growing plants in saline media come across generally with major drawbacks; the first is the increase in the osmotic stress due to high salt concentration of soil solution that decreases water potential of soil; the second is the increase in concentration of $\mathrm{Na}$ and $\mathrm{Cl}$, exhibiting tissue accumulation of $\mathrm{Na}$ and $\mathrm{Cl}$, and inhibition of mineral nutrients uptake.

Concerning the effect of other magnetized water or humic acid levels, data in same Tables showed abviosuly that, increasing the level of humic acid (30 $\mathrm{cm}$.) from one hand irrigated seedlings with magnetic water from another exhibited statistically increased in leaf ( $N$, $\mathrm{P}, \mathrm{K}, \mathrm{Mg}, \mathrm{Fe}, \mathrm{Zn}$ and $\mathrm{Mn}$ ) contents and significantly decreased in leaf $(\mathrm{Ca}$, NaandCl) contents of pear rootstock seedlings during the two seasons of study.

Regarding the interaction effect of different combinations between the various variable of three investigated factors on leaf nutrient contents of pear rootstock seedlings, data in the last Tables displyed clearly that, the specific effect of each studied factor i.e.,(salinity, magnetized water and humic acid) was directly reflected on their combination during the two seasons in this study. In the other words, the pear seedlings were irrigated with the highest saline water concentration,combined with nonmagnetized water and non applied of humic acid i.e.,(3000 mg/l, non- 


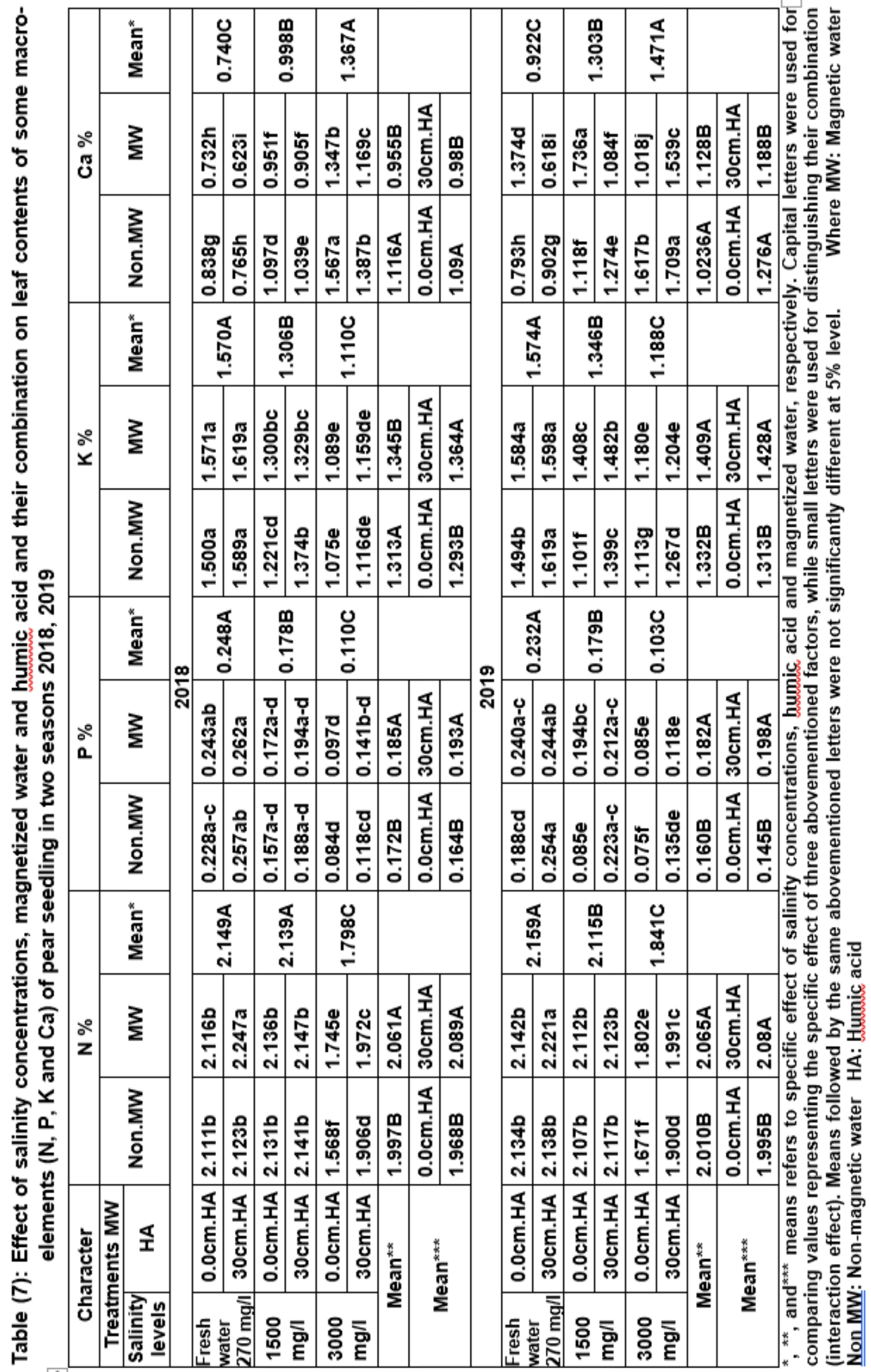




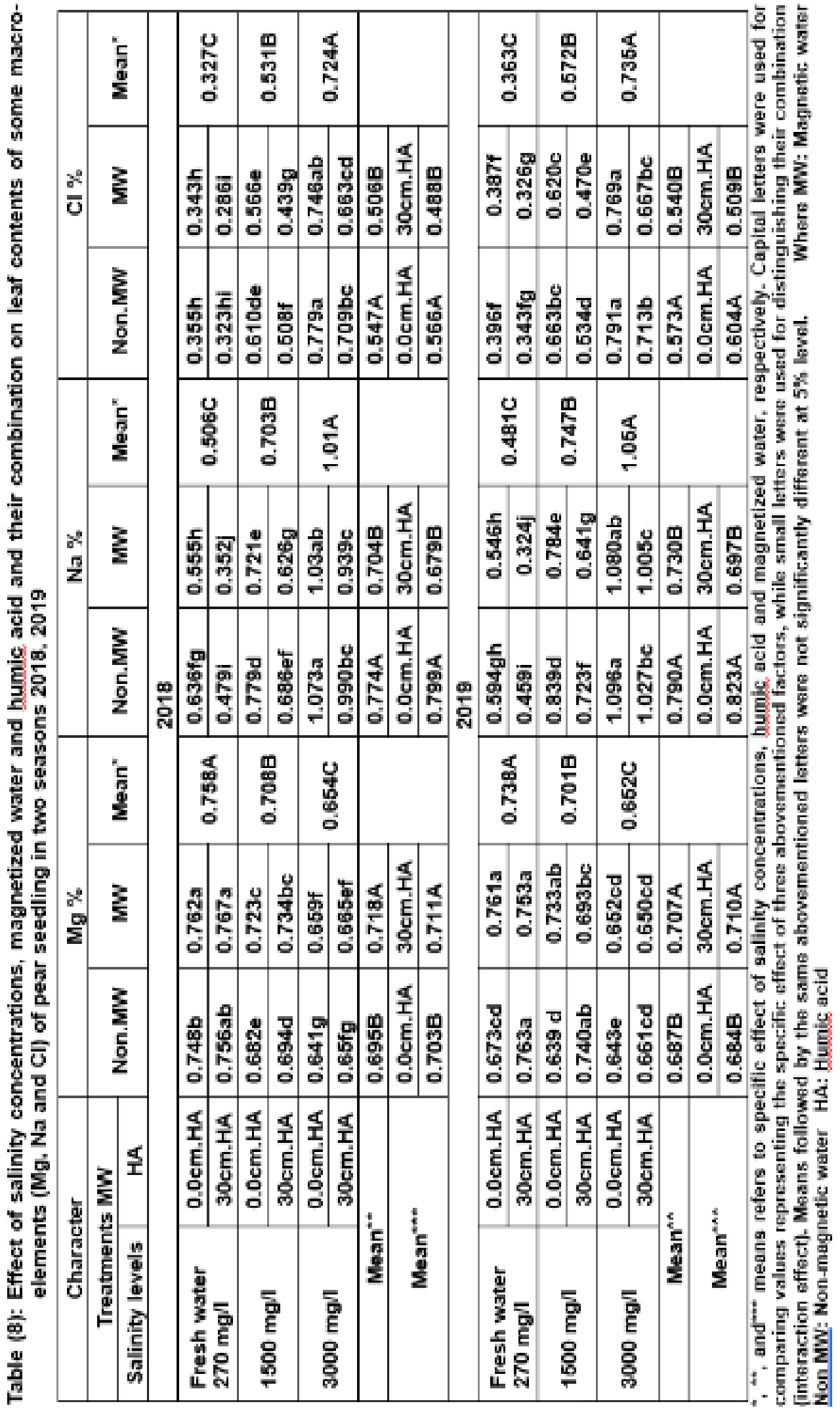




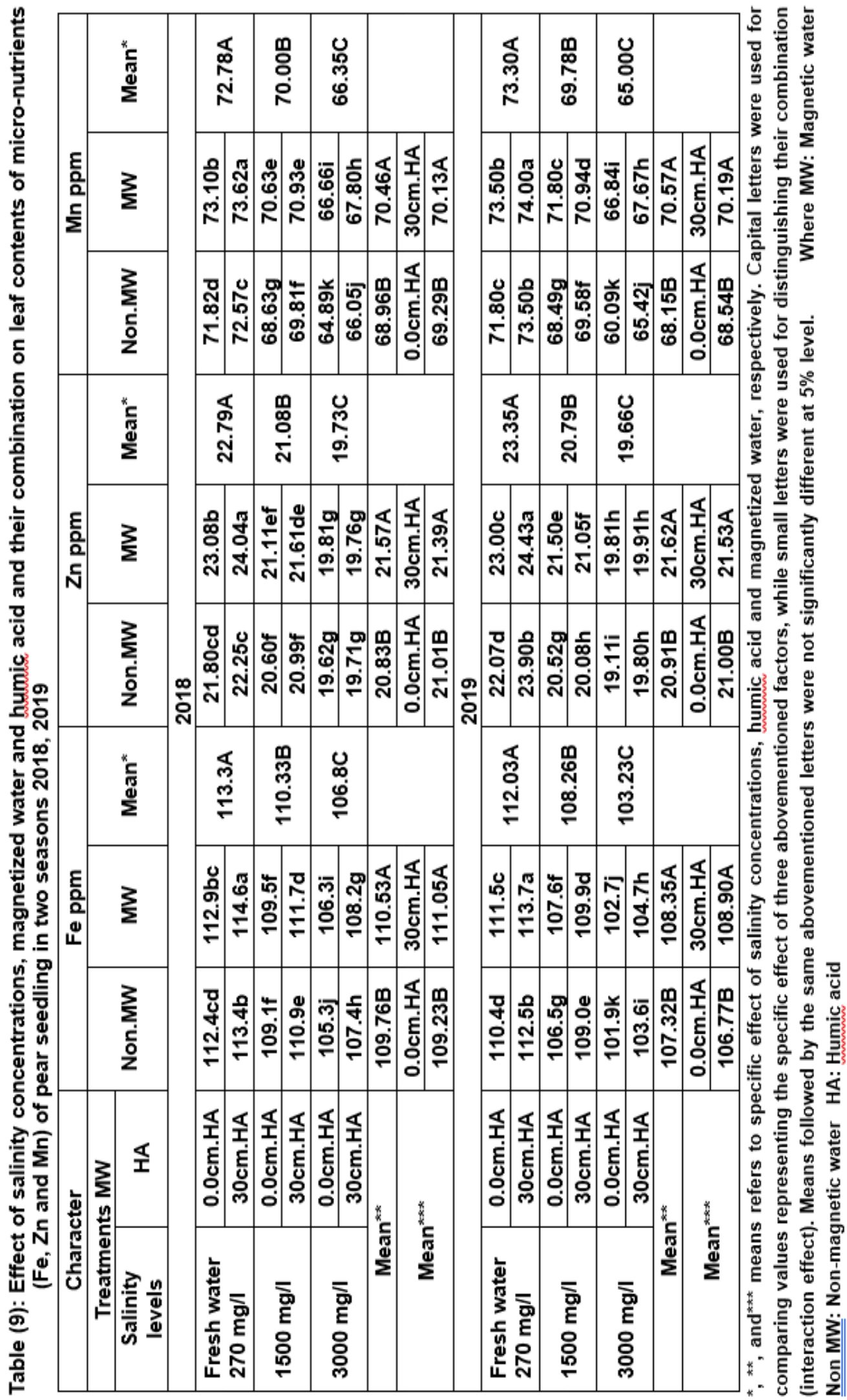


magnetized water and 0.0 humic acid) treatment had the poorest leaves in their nutrient contents ( $N, P, K, M g, F e, ~ Z n$ and $\mathrm{Mn})$.

The obtained results are in agreement with those of Aly et al. (2015), who found that magnetic water caused an increase in nitrogen,phosphorus, potassium, calcium, and magnesium in Valencia orange leaves. Soliman et al. (2017), who idicated that, irrigation by magnetic water exhibited an increase in (macro nutrient) nitrogen, potassium and phosphorous contents and (micro nutrient) iron, manganese, copper and zinc contents compared with leaves irrigated with nonmagnetic water of grape leaves.

However,the reserve trend was observed with leaf $(\mathrm{Ca}, \mathrm{Na}$ and $\mathrm{Cl}$ ) contents in both seasons. On the other hand, the richest leaves of nutrient contents and the highest values of leaf $(N$, $\mathrm{P}, \mathrm{K}, \mathrm{Mg}, \mathrm{Fe}, \mathrm{Zn}$ and $\mathrm{Mn}$ ) contents were always in concomitant to the pear seedlings irrigated with.,(270 mg/l, magnetic water and humic acid applied) treatment

Generally, it could be indicated that the irrigation of pear seedling rootstock with magnetic water exhibited a positive effect on either macro or micro-nurients among the role of magnetic water in reducing the harmful effects of salinity through salublizing $\mathrm{NaCl}$ salt and leaching at out of the soil. Therefore, the plants do not uptake higher amounts of either $\mathrm{Na}$ or $\mathrm{Cl}$. Also, the magnetic water improved dissolving of nutrients in the soil irrigated with magnetized water and increases in the rate of water absorption, and explianed the results by the variations induced by magnetic fields in the ionic currents across the cellular membrane with leads to change in the osmotic pressure (Carbonell et al., (2004).

\section{CONCLUSION}

In general, the use of magnetized water technique with humic acid applications (30 cmlplantlyear) would be an economically and safe alternative tool to resolve the problem of irrigating with saline water and to enhance pear rootstock seedlings growth grown under similar conditions of this study.

\section{REFERENCES}

Aladjadjiyan, A. (2010). Influence of stationary field on lentil seeds. Int. Agrophys., 24: 321-324.

Alikamanoglu, S. and A. Sen (2011). Stimulation of growth and some biochemical parameters by field in wheat (Triticum aestivum L.) tissue cultures. African Journal of Biotechnology, 10: 10957-10963.

Aly, M. A., M. Thanaa, E., S. M. Osman and A. A. A. Mazek (2015). Effect of Magnetic Irrigation Water and Some Anti-Salinity Substances on the Growth and Production of Valencia Orange. Middle East J. Agric. Res., 4(1): 88-98.

Al-yassin, A. (2005). Adverse effect of salinity on citrus. Inter. J. Agri. and Biology.07(4):668-680.

Atkinson, C.J., A. D. Webster, S. P. Vaughan, L. Tolyor and G. Kingswell (2000). Interaction between root reduction,irrigation and rootstock treatments on queen cox apple trees:effect of soil and plant water relation. Jour. Hort. Sci. Biotech.,75: 376-382.

Batels, L.S., R.P. Waldren and I.D. Teare (1973). Rapid determination of free proline for water stress studies. Plant and Soil: 939: 205-207.

Brito, M.E.B., K.S. Arruda, P.D. Fernandes and A.D. Xevier (2014). Growth of ungrafted and grafted citrus rootstocks under saline water 
irrigation. Academic J.9 (50):36003609.

Carbonell, M.V., E. Martinez, J.E. Diaz, J.M. Amaya and M. Florez (2004). Influence of magnetically treated water on germination of signal grass seeds. Seed Science and Technology, 32(2): 617-619.

Cottenie, A., M. Verloo, L. Kiekens, G. Velghe and R. Camerlynck (1982). Chemical analysis of plants and soils. Laboratory of Analytical and Agro chemistry State University, GhentBelgium.

Chapman, H.D. and P.F. Pratt (1961). Methods of Analysis for Soils; Plants and Waters. Div. Agric. Sci. Univ. California, Berkely pp. 309.

Chen, Y., M. De Nobili and T. Aviad (2004). Stimulatory Effects of Humic Substances on Plant

Dhawi, F. and J. M. Al-Khayri (2009). The effect of magnetic resource imaging on Date palm (Phoenix dactylafera L.) demental composition. communication in biometry and crop science,4 (1):1420.

Draz, M.Y. (1986). Response of bitter almond seedling to different water regime. Ph. D. Thesis Fac. of Agric., Cairo Univ. Egypt.

Duncan, B.D. (1955). Multiple test range and multiple $F$ tests. Biometrics, 11142.

El-Nagar, P.S. (1996). effects of magnetized saline water on growth development of winter wheat seedlings. Adv. J. Food Sci. Technol., 5; 1496-1499.

Goldsworthy, A. H., H. Whitney and E. Morris (1999). Biological effect of physical condition water. Rose, 33 (7); 1618-1626.

Gusov, N.A. (1960). Some methods in studying plant water relations. Leningrad Acad. of Sci., USSR.
Halma, F.F. (1934). Trunk growth and water relations in the leaves of citrus. Proc. Amer. Soc. Hort. Sci., 32: 273276.

Klute, A. (1986). Methods of Soil Analysis: Part I: Physical and Mineralogical Methods. (2nd Ed), Am. Soc. Agron. Monograph No. 9, Madison, Wisconsin. USA.

Mesut, C. K., T. Onder, T. Metin and T. Burcu (2010). Phosphorus and humic acid application alleviate salinity stress of pepper seedling. African Journal of Biotechnology, 9: 58455851.

Mohamed, A. I. (2013). Effects of Magnetized Low Quality Water on Some Soil Properties and Plant Growth. Int. J. Res. Chem. Environ., 3:140- 147.

Mostafazadeh, F. B., M. Khoshravesh, S. Mousavi and A. Kiani (2011). Effects of magnetized water and irrigation water salinity on soil moisture distribution in trickle irrigation. Journal of Irrigation and Drainage Engineering. 137(6); 398402.

Moussa, H. R. (2011). The impact of magnetized water application for improving common bean (Phaseolus vulgaris L.) production. New York Science Journal. 4(6); 15-20.

Mpelasoka, B.S., M.H. Behbodian and T.M. Mills (2001). water relation, photosynthesis, growth, yield and fruit size of braeburn apple: responses to deficit irrigation and to crop load. G. Hort. Sci. Biotech., 70;150-156.

Murphy, J. and J.P. Riely (1962). A modified single dilution method for determination of phosphate in natural water. Anol chem (Acta, 27:31-36).

Nomir, S.A. (1994). Physiological studies on kaki. Ph. D. Thesis., Fac. of Agric. Zagazig Univ. Egypt.

Osman, E.A. M., K. M. Abd El-Latif, S. M. Hussien and A.E.A. Sherif (2014). 
Assessing the effect of irrigation with different levels of saline water on growth parameters and mineral contents of pear seedlings. Global Journal of Scientific Researches, 2(5): 128-136.

Page, A.L., R.H. Miller and D.R. Keeny (1982). Methods of Soil Analysis, Part II. Chemical and Microbiological Properties. ( $\left.2^{\text {nd }} \mathrm{Ed}\right), \mathrm{Am}$. Soc. Agron. Monograph No. 9, Madison, Wisconsin, USA.

Paranava, P., A. K. Singh, A. K. Dubey and O.P. Awasthi (2014). Effect of salinity stress on growth and nutrient uptake on polyembryonic mango rootstock. Indian, Hort., 71: 28-34.

Peynado, A. and R. H. Young (1968). Moisture changes in intact leaves monitord by $B$ guage technique. Proc. Amer. Soc. Hort. Sci., 92: 211-220.

Pregl, F. (1945). Quantitative organic micro- analysis $4^{\text {th }}$ Ed. J. and $A$ Churvhill, Ltd. London.

Qudos, A. and M. Hozayn (2010). water technology, a novel tool to increase growth, yield, and chemical constituents of lentile (Lens esculenta) under greenhouse conditions.
American- Eurazian J. Agric. And Environ. Sci., 7 (4):457-462.

Radhakrishnan, R. and B.D.R. Kumari (2012). Pulsed field: A contemporary approach offers to enhance plant growth and yield of soybean. Plant Physiology and Biochemistry, 51: 139144.

Saric, M., R. Kastrori, R. Curic and L. Geric (1967). Effect of salinity on some citrus rootstocks. Prak Fiziol. Anjiga, pp. 215.

Snedecor, G.W. and W. G. Cochran (1990). Statistical Methods. $6^{\text {th }}$ ed. The towa state, Univ. Press, Amer, lowa, U.S.A. PP. 593.

Soliman, E. M., Doaa, M. Hammad and Shaimaa F. Zaky (2017). Effect of irrigation with magnetic saline ground water on soil and grape crop. J. Environ. Sci. Institute of Environmental Studies and Research, Ain Shams University. Vol. 38, No.1, pp.83-103

Varanini, Z and R. Pinton (2001). Direct versus indirect effects of soil humic substances on plant growth and nutrition. In: The rhizosphere: biochemistry and organic substances at the soil-plant interface (Pinton R., Varanini Z., Nannipieri P., eds). Marcel Dekker Inc, NY, USA. pp. 141-157. 
استجابة شتلات الكمثرى لبعض مياه الري المالحة والممغنطة وحمض الهيوميك وتأثيرها على النمو والصفات الفسيولوجية والصبغات والمحتوى المعدنى للاورلق

حسين قابيل ابراهيم(')، درويش رجب درويش(')، يحيى ابراهيم النجار (')،

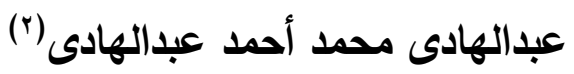

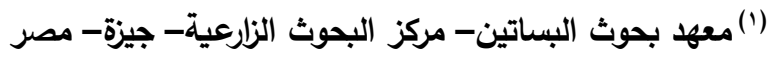

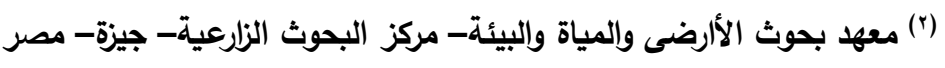

الملخص العبى

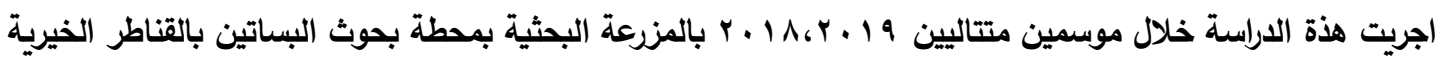

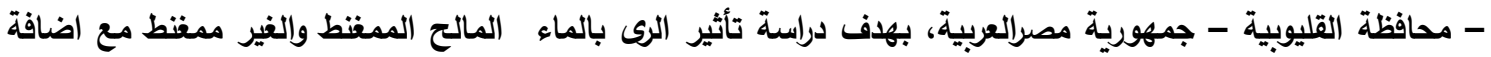

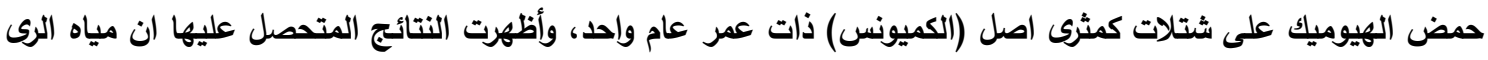

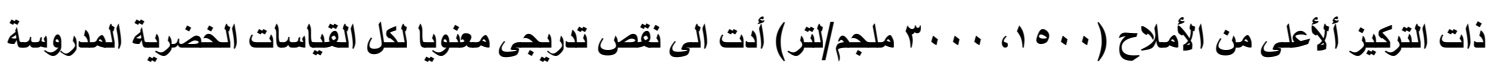

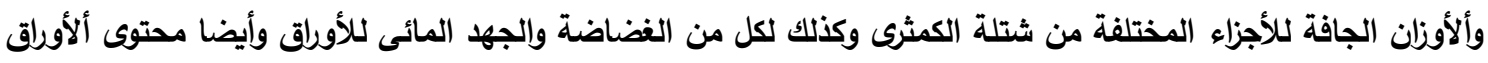
من الصبغات اضافة الى محتوى ألأولق من بعض العناصر (نيتروجين - فوسفور - بوتاسيوم - ماغنسيوم - حديد - زنك الكاء

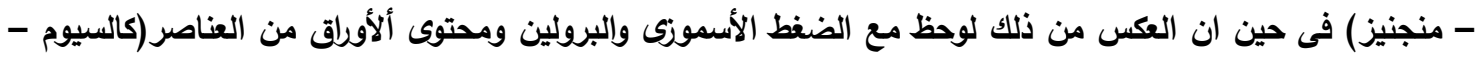

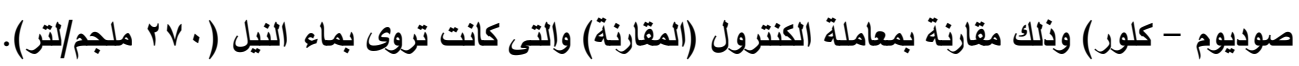

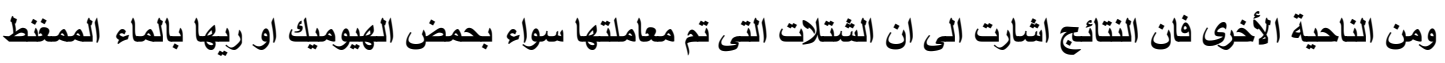

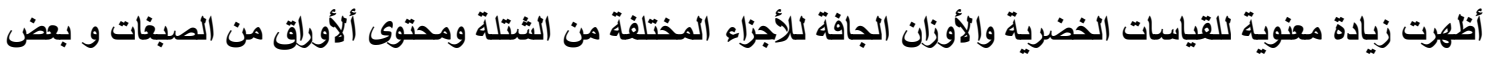

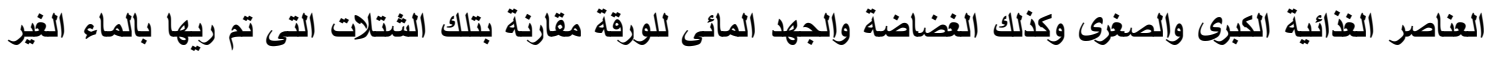

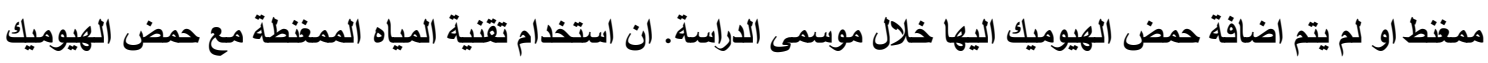

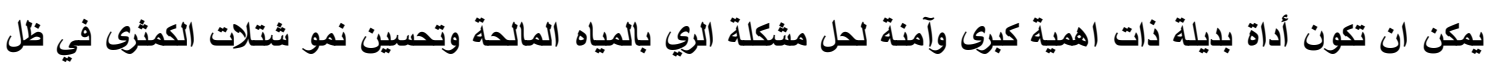
ظروف مماثلة لهذه الدراسة. 
H. Kabeel, et al., 